\section{Caution is sensible, but give biotech a chance to show the good it can do}

Sir - On behalf of the Italian Society of Agricultural Genetics (SIGA), I wish to express our astonishment and concern over the televised statement and other reported comments made by Alfonso Pecoraro Scanio, the Italian minister for agricultural and forestry policy, during the International Biotechnology Congress in Genoa on 23-26 May (Nature 405, 388 ; 2000).

Officials from his ministry were banned from taking part in the congress, despite having previously agreed to present their work on biosafety and on important progress that had been achieved in the ministry's own research institutes. Also, the minister has expressed his intention to ban controlled field experiments of genetically modified plants. In practice, this means a halt to research, whether in applied sectors or in biosafety.

SIGA totally supports the principle that scientific research programmes should undergo rigorous assessment of their objectives, techniques, applications and consequences for society and the environment. Nonetheless, technological innovation is bringing about numerous positive changes, generating increasingly widespread expectations and reactions. There is an uncertain future in store for countries whose state-funded research is underresourced and inadequate.

SIGA's members (more than half of whom are under 35 years old) are well aware of their responsibilities as academic researchers in the service of the public good - they are not unthinking advocates of the biotechnology market. This is why we feel that the minister's televised invitation to Italian students and researchers to abandon agricultural biotechnology research and devote themselves to the medical sector "which at least saves human lives" is serious cause for concern.

Of course, no human undertaking is risk-free. An innovation is acceptable if its introduction does not prove hazardous by any known criteria. Hence SIGA requests the Italian government - in consultation with the National Commission for Biosafety and Biotechnology, scientific societies and academies, consumer associations, environmental organizations and businesses - to proceed with the application of due precautionary measures to test genetically modified plants in segregated areas, so that their impact on the health and well-being of humankind and the environment can be studied and monitored.

The relationship between science and society is an inescapable feature of the scientist's profession. Scientists have to question the social effects of their research and appreciate the need for clear communication. The possibility of distorted and hazardous use of new technologies threatens society and causes public mistrust.

On the other hand, scientific research advances the frontiers of knowledge, giving rise to innovations whose production, development and economic use may benefit society. Consequently, biotechnology must be assessed not only in terms of possible risks, but also for the benefits which it may afford in regard to human life and dignity, human rights and values, environmental protection and natural-resource conservation (especially biodiversity).

SIGA is committed to promoting study and research programmes in keeping with these wider goals of science, and to participate in public information programmes. Enrico Porceddu

Italian Society of Agricultural Genetics (SIGA), Department of Agrobiology and Agrochemistry, University of Tuscia, 01100 Viterbo, Italy

\section{A fault in the 'weak San Andreas' theory}

Sir - Over the past few decades a modern theory of earthquake physics has been developed that is solidly based upon the laws of rock friction ${ }^{1}$. Ironically, over that same period there has emerged a view that, alone among crustal faults, California's San Andreas fault grossly violates those laws, while still generating earthquakes indistinguishable from those on other crustal faults. This conclusion is based on the absence of a heat-flow anomaly adjacent to the San Andreas fault that would be expected from a conductive model of frictional heating a conclusion that requires the friction on the fault to be exceedingly low compared to that of any plausible geological material.

In testing this hypothesis with stress data $^{2}$, I found much of these data ambiguous, but throughout Southern California the data unambiguously indicated that the San Andreas fault is not weak relative to the surrounding crust. This model-independent conclusion is in strong conflict with the heat-flow interpretation. Mark Zoback, in commenting on my results in News and Views ${ }^{3}$, reiterated the heat-flow interpretation as the strongest argument for a lowstrength fault, which indeed it is.

As Sherlock Holmes noted about the dog barking in the night-time, the curious thing about the conductive heat-flow anomaly is its absence. There is, however, a broad heat-flow anomaly associated with the San Andreas fault ${ }^{4}$, large enough to account for frictional heating on a strong fault. Heat flow in this anomaly shows very high spatial scatter, suggesting, together with its breadth, a heat-transport mechanism other than conduction.

Townend and Zoback ${ }^{5}$ show that crustal scale permeability, owing to the presence of active faults, is high enough to ensure that pore pressures are ubiquitously hydrostatic in the crust. Such high fracture permeability would strongly favour advection by fluid transport along fractures, which can transport large heat fluxes without generating massive hot-spring activity ${ }^{6}$. It seems there are cracks in the heat-flow edifice.

\section{H.Scholz}

Lamont-Doherty Earth Observatory, Columbia University, Palisades, New York 10964, USA

1. Scholz, C. H. Nature 391, 37 (1998).

2. Scholz, C. H. Geology 28, 163-166 (2000).

Zoback, M. Nature 405, 31 (2000)

4. Lachenbruch, A. H. \& Sass, J. H. J. Geophys. Res. 85, 6185-6222 (1980).

5. Townend, J. \& Zoback, M. D. Geology 28, 399-403 (2000).

6. Manga, M. Geology 26, 799-802 (1998).

\section{That famous double helix takes a sinister turn}

Sir - The double-helical structure of DNA is one of the most recognizable scientific images, and one of the most frequently abused. In particular, it is often shown as a left-handed instead of a right-handed helix.

The announcement last month that the first draft of the human genome is complete has featured prominently in the national news, frequently accompanied by left-handed helices.

More worrying than this mistake made by the popular press is the frequency with which DNA is wrongly depicted in the scientific press, particularly that of the genetics community. Such errors do little to inspire confidence.

Nature has no excuse for depicting lefthanded helices in a figure to an Insight article about functional genomics ${ }^{1}$, or for claiming in a Book review that Franklin's $\mathrm{X}$-ray crystallograph "led Watson and Crick to deduce the left-handed doublehelical structure of DNA"2.

On the contrary, Watson and Crick's original article ${ }^{3}$ describes (and illustrates!) a right-handed sense.

\section{Colin Porter}

Institute of Cancer Research, Fulham Road, London SW3 6JB, UK

1. Vukmirovic, O. G. \& Tilghman, S. M. Nature 405, 821 (2000).

2. Nature 405,737 (2000).

3. Watson, J. D. \& Crick, F. H. C. Nature 171, 737 (1953).

Nature replies - This is correct, and we will be more vigilant in future. See http://www-lmmb.ncifcrf.gov/ toms/ LeftHanded.DNA.html for a comprehensive general discussion of this problem. 